\title{
Faktor-Faktor Kesulitan Belajar Matematika Siswa Madrasah Ibtidaiyah Da'watul Falah Kecamatan Tegaldlimo Kabupaten Banyuwangi
}

\author{
Mohammad Kholil \\ IAIN Jember \\ muad.kholil@gmail.com \\ Silvi Zulfiani \\ IAIN Jember \\ kunyil505@gmail.com
}

\begin{abstract}
Abstrak
Salah satu mata pelajaran yang dianggap sulit oleh siswa adalah matematika. Sehingga pelajaran ini kurang diminati siswa. Permasalahan inilah yang menyebabkan banyak siswa mengalami kesulitan belajar matematika. Rumusan masalah dalam penelitian ini yaitu: Kesulitan Belajar Matematika Siswa MI Da'watul Falah Kecamatan Tegaldlimo Kabupaten Banyuwangi Tahun Pelajaran 2018/2019? Sedangkan tujuan penelitian ini adalah untuk mendeskripsikan kesulitan belajar matematika siswa MI Da'watul Falah Kecamatan Tegaldlimo Kabupaten Banyuwangi. Penelitian ini menggunakan pendekatan kualitatif dengan jenis penelitian fenomenologi. Subjek penelitian dalam penelitian ini menggunakan purposive sampling. Teknik pengumpulan data yang digunakan adalah observasi, wawancara, dan dokumentasi. Sedangkan analisis data menggunakan model analisis Miles, Huberman dan Saldana yaitu data Condensation, data Display, serta Conclusion drawing/verivication. Adapun pengecekan keabsahan data yang digunakan adalah triangulasi sumber dan triangulasi teknik. Hasil penelitian ini menunjukkan bahwa kesulitan belajar matematika siswa disebabkan salahnya mindset yang dibangun dari awal oleh siswa, sehingga mereka kesulitan dalam memahami materi yang diajarkan di kelas. Adapun faktor-faktor yang menyebabkan kesulitan belajar terdiri dari faktor internal dan faktor eksternal.
\end{abstract}

Kata Kunci:Faktor Kesulitan Belajar; Matematika 


\section{PENDAHULUAN}

Matematika diberikan untuk membekali peserta didik untuk berpikir logis, analitis, sistematis, kritis, dan kreatif, serta kemampuan bekerjasama. ${ }^{1}$ Mata pelajaran matematika di sekolah dasar mempelajari tiga cabang yaitu aritmetika, aljabar, dan geometri. ${ }^{2}$ Kemampuan-kemampuan yang diberikan melalui pelajaran matematika sebagaimana tercantum dalam fungsi pendidikan nasional yang berdasarkan pada Undang-Undang Dasar Republik Indonesia Tahun 1945 yang berbunyi mengembangkan kemampuan dan membentuk watak serta peradaban bangsa yang bermartabat dalam rangka mencerdaskan kehidupan bangsa. ${ }^{3}$ Salah satu kemampuan yang harus dimiliki siswa dalam belajar dan memahami matematika adalah bernalar atau berpikir logis. ${ }^{4}$

Pembelajaran matematika yang diajarkan di sekolah bertujuan agar peserta didik memiliki kemampuan sebagai berikut: (1) Memahami konsep matematika; menjelaskan keterkaitan antar konsep dan mengaplikasikan konsep atau algoritma secara luwes, akurat, efisien, dan tepat, dalam pemecahan masalah; (2) menggunakan penalaran pada pola dan sifat, melakukan manipulasi matematika dalam membuat generalisasi, menyusun bukti, atau menjelaskan gagasan dan pernyataan matematika; (3) memecahkan masalah yang meliputi kemampuan memahami masalah, merancang model matematika, menyelesaikan model, dan menafsirkan solusi yang diperoleh; (4) mengkomunikasikan gagasan dengan simbol, tabel, diagram, atau media lain untuk memperjelas keadaan atau masalah;

\footnotetext{
${ }^{1}$ Mohammad Kholil, "Membangun Kemampuan Koneksi Matematika Melalui Strategi Interaksi Peserta Didik Program Studi Pendidikan Guru Madrasah Ibtidaiyah (PGMI) Institut Agama Islam Negeri (IAIN) Jember," FENOMENA 15, No. 2 (December 29, 2016): 351-70.

${ }^{2}$ Mulyono Abdurrahman, Anak Berkesulitan Belajar (Teori, Diagnosis, Dan Remediasinya), (Jakarta: Rineka Cipta, 2012).

${ }^{3}$ Tim Fokusmedia, Undang-Undang SISDIKNAS Sistem Pendidikan Nasional, (Bandung: Fokus Media, 2015).

${ }^{4}$ Mohammad Kholil, "Implementasi Pembelajaran Inquiry Untuk Meningkatkan Kemampuan Berpikir Logis Pada Pokok Bahasan Logika Matematika," LAPLACE: Jurnal Pendidikan Matematika 1, no. 1 (2018): 15-25.
} 
(5) memiliki sikap menghargai kegunaan matematika dalam kehidupan, yaitu memiliki rasa ingin tahu, perhatian, dan minat dalam mempelajari matematika, serta sikap ulet, dan percaya diri dalam pemecahan masalah. ${ }^{5}$ Dalam proses pembelajaran matematika siswa harus memunculkan dorongan-dorongan untuk menemukan pengalaman baru agar tujuan dalam pembelajaran dapat tercapai. ${ }^{6}$

Upaya untuk mencapai tujuan pembelajaran matematika terdapat berbagai permasalahan yang dihadapi salah satunya yaitu persepsi siswa mengenai mata pelajaran matematika. Siswa menganggap bahwa mata pelajaran matematika adalah mata pelajaran yang sulit dan membosankan, sehingga menyebabkan banyak siswa kurang menyukai mata pelajaran matematika, bahkan menjadikan matematika sebagai momok yang harus dihindari. Seperti yang diungkapkan oleh Abdurrahman bahwa dari berbagai bidang studi yang diajarkan di sekolah, matematika merupakan bidang studi yang dianggap paling sulit oleh para siswa, baik yang tidak berkesulitan belajar dan lebih-lebih bagi siswa yang berkesulitan belajar. ${ }^{7}$ Hal ini menyebabkan siswa yang kurang menyukai pelajaran matematika mengalami kecemasan yang membuat kesulitan dalam memahami materi yang disampaikan dan berdampak pada rendahnya prestasi belajar matematika.

Permasalahan yang dipaparkan diatas menyebabkan banyak siswa mengalami kesulitan dalam belajar matematika. Kesulitan belajar atau learning disability adalah suatu keadaan yang membuat individu sulit untuk

\footnotetext{
${ }^{5}$ MENDIKBUD, Peraturan Menteri Pendidikan Dan Kebudayaan Republik Indonesia Nomor 21 Tahun 2016 Tentang Standar Isi Pendidikan Dasar Dan Menengah, (Jakarta: Menteri Pendidikan dan Kebudayaan, 2016).

${ }^{6}$ Mohammad Kholil and Olvi Safianti, "Efektivitas Pembelajaran Penemuan Terbimbing Terhadap Hasil Belajar Matematika Siswa Materi Barisan Dan Deret," Laplace: Jurnal Pendidikan Matematika 2, no. 2 (November 25, 2019): 89-98, doi:10.31537/laplace.v2i2.246.

${ }^{7}$ Mulyono Abdurrahman, Pendidikan Bagi Anak Berkesulitan Belajar, (Jakarta: Rineka Cipta, 2010).
} 
melakukan kegiatan belajar secara efektif. ${ }^{8}$ Daniel Franklin mengemukakan bahwa kesulitan belajar adalah suatu kondisi yang menimbulkan hambatan dalam proses belajar seseorang. ${ }^{9}$ Hambatan tersebut menyebabkan orang tersebut mengalami kegagalan atau setidak-tidaknya kurang berhasil dalam mencapai tujuan belajar.

Faktor yang menjadi penyebab kesulitan belajar tidaklah mudah untuk ditetapkan karena faktor tersebut bersifat kompleks. ${ }^{10}$ Kesulitan belajar ini tidak selalu disebabkan karena faktor inteligensi yang rendah (kelainan mental), akan tetapi juga disebabkan oleh faktor-faktor non-inteligensi. ${ }^{11}$ Ahmadi dan Supriyono menyatakan bahwa faktor kesulitan belajar terbagi menjadi dua, yaitu (1) faktor intern (faktor dari dalam diri manusia); dan (2) Faktor ekstern (faktor dari luar manusia). ${ }^{12}$ Faktor intern terdiri dari:1) Sikap terhadap belajar; 2) Motivasi belajar; 3) Konsentrasi belajar; 4) Kemampuan mengolah bahan belajar; 5) Kemampuan menyimpan perolehan hasil belajar; 6) Menggali hasil belajar yang tersimpan; 7) Kemampuan berprestasi; dan 8) Rasa percaya diri siswa. Sedangkan Faktor ekstern yang dapat mempengaruhi aktivitas belajar siswa terdiri dari 1) Guru sebagai pembina siswa dalam belajar; 2) Sarana dan prasarana pembelajaran; 3) Kebijakan penilaian; 4) Lingkungan sosial siswa di sekolah; dan 5) Kurikulum sekolah. ${ }^{13}$

Berhubungan dengan kesulitan belajar ini, telah dilakukan beberapa penelitian sebelumnya. Diantaranya adalah penelitian yang dilakukan oleh Lee Swanson dalam Schiff dan Joshi mengatakan bahwa siswa dengan

\footnotetext{
${ }^{8}$ Ika Maryani et al., Model Intervensi: Gangguan Kesulitan Belajar, (Jogjakarta: KMedia, 2018).

${ }^{9}$ Daniel Franklin, Helping Your Child with Language-Based Learning Disabilities: Strategies to Succeed in School \& Life with Dyslexia, Dysgraphia, Dyscalculia, ADHD \& Processing Disorders, (Canada: New Harbinger Publications, 2018).

${ }^{10}$ Martini Jamaris, Kesulitan Belajar: Perspektif, Asesmen, Dan Penanggulangannya, (Bogor: Ghalia Indonesia, 2015). 2013).

${ }^{11}$ Abu Ahmadi and Widodo Supriyono, Psikologi Belajar, (Jakarta: Rineka Cipta,

${ }^{12}$ Ibid.79

${ }^{13}$ Maryani et al., Model Intervensi: Gangguan Kesulitan Belajar.
} 
kesulitan belajar matematika merupakan individu yang memiliki performa normal dalam tes intelegensi, akan tetapi memiliki kekurangan dalam mentrasnformasikan kalimat ke dalam bahasa matematika. ${ }^{14} \mathrm{Hal}$ ini terjadi karena lemahnya kemampuan kognitif siswa serta kurangnya minat siswa terhadap matematika. Selanjutnya Waskitoningsih dalam penelitiannya mengatakan bahwa kesulitan belajar matematika yang dialami siswa 76,7\% mengalami kesulitas dalam hal memahami prinsip (teorema atau dalil) matematika. Hal ini dipengaruhi oleh faktor intern dan ekstern. ${ }^{15}$

Selanjutnya kondisi siswa di MI Da'watul Falah Tegaldlimo Kabupaten Banyuwangi. Berdasarkan hasil wawancara dengan guru matematika MI Da'watul Falah sebagian siswa mengalami kesulitan dalam belajar matematika. Siswa kelas 4, 5, dan 6, dalam 1 kelas hanya terdapat sedikit sekali yang berminat dalam matematika yaitu sebesar $25 \%$ dari jumlah siswa yang ada. Hal ini terlihat siswa kurang aktif saat diminta untuk mengerjakan soal-soal matematika dan hanya ada beberapa siswa yang berani maju di depan kelas untuk mengerjakan soal tersebut. Masalah ini perlu segera diselesaikan serta dicari solusi yang tepat untuk memcahkan masalah ini. Oleh karena itu, dilakukan penelitian tentang faktor kesulitan belajar matematika di MI Da'watul Falah Tegaldlimo Kabupaten Banyuwangi. Sedangkan tujuan penelitian ini adalah mendeskripsikan fakto-faktor kesulitan belajar matematika siswa MI Da'watul Falah Kecamatan Tegaldlimo Kabupaten Banyuwangi.

\footnotetext{
${ }^{14}$ Rachel. Schiff and R. Malatesha. Joshi, Interventions in Learning Disabilities : A Handbook on Systematic Training Programs for Individuals with Learning Disabilities, (Switzerland: Springer International Publishing, 2016), doi:10.1007/978-3-319-31235-4.

${ }^{15}$ Rahayu Sri Waskitoningtyas, "Analisi Kesulitan Belajar Matematika Siswa Kelas V Sekolah Dasar Kota Balikpapan Pada Materi Satuan Waktu," Jurnal Ilmiah Pendidikan Matematika 5, no. 1 (2016): 24-32.
} 


\section{METODE PENELITIAN}

Pendekatan yang digunakan dalam penelitian ini adalah pendekatan kualitatif dengan jenis penelitian fenomenologi. Penelitian jenis fenomenologi bertujuan untuk memahami secara rinci tentang suatu fenomena yang terjadi dilokasi penelitian. ${ }^{16}$ Dalam hal ini adalah faktorfaktor kesulitan belajar matematika yang dialami siswa.

Adapun lokasi penelitian ini bertempat di MI Da'watul Falah yang beralamatkan di Jl. Raya Plengkung Indah, No.9B, Kedungwungu, Kecamatan Tegaldlimo, Kabupaten Banyuwangi. Lokasi ini dipilih sebagai tempat penelitian karena di madrasah ini $75 \%$ siswa kelas tinggi mengalami kesulitan belajar matematika. Sedangkan subjek penelitian dalam penelitian ini menggunakan purposive sampling. Sugiyono mengatakan, bahwa purposive sampling adalah teknik pengambilan sampel sumber data dengan pertimbangan tertentu. ${ }^{17}$ Hal ini sesuai dengan pendapat Creswellyang mengatakan bahwa purposive sampling merupakan teknik pengambilan sampel yang dilandasi dengan tujuan atau pertimbangan tertentu terlebih dahulu. ${ }^{18}$ Oleh karena itu, informan dalam penelitian ini adalah 1) Kepala madrasah MI Da'watul Falah yaitu Bapak Jaenuri, 2) guru kelas 4 yaitu Ibu Isti'anah dan guru kelas 5 yaitu Ibu Hindun Rahmawati, 3) guru mata pelajaran matematika yaitu Bapak Muhammad Zainul Gufron, dan 4) siswa kelas 4 dan kelas 5 .

Teknik pengumpulan data yang digunakan dalam penelitian ini adalah observasi, wawancara, dan dokumentasi. ${ }^{19}$ Sedangkan analisis data yang digunakan sesuai dengan pendapat Miles, Huberman dan Saldana yaitu data

\footnotetext{
${ }^{16}$ Emzir, Metodologi Penelitian Kualitatif Analisis Data, (Jakarta: Rajawali Pers, 2016).

${ }^{17}$ Sugiyono, Metode Penelitian Pendidikan (Pendekatan Kuantitatif, Kualitatif Dan $R \& D)$ (Bandung: Penerbit CV. Alfabeta, 2017).

${ }^{18}$ John W. Creswell and J. David Creswell, Research Design: Qualitative, Quantitative, and Mixed Methods Approaches, Fitth Edit (United States of America: SAGE Publications, Inc, 2018).

${ }^{19}$ Sugiyono, Metode Penelitian Pendidikan (Pendekatan Kuantitatif, Kualitatif Dan $R \& D)$.
} 
Condensation, data Display, serta Conclusion drawing/verivication. ${ }^{20}$ Adapun pengecekan keabsahan data yang digunakan dalam penelitian ini adalah triangulasi sumber dan triangulasi teknik.

Triangulasi sumber dilakukan dengan cara menganalisa dan membandingkan kebenaran data yang diperoleh dari beberapa sumber ${ }^{21}$, yaitu Kepala Madrasah MI Da'watul Falah, guru mata pelajaran matematika, guru kelas 4 dan 5, dan siswa kelas 4 dan 5. Data yang telah dianalisis oleh peneliti sehingga menghasilkan suatu kesimpulan selanjutnya diminta kesepakatan (member check) dengan sumber data tersebut. Sedangkan triangulasi teknik dalam penelitian ini dilakukan dengan cara mengecek data kepada sumber yang sama dengan teknik yang berbeda. ${ }^{22}$

\section{HASIL DAN PEMBAHASAN TEMUAN}

Penelitian ini menggunakan metode observasi, wawancara, dan dokumentasi sebagai alat untuk memperoleh data yang sesuai dengan rumusan permasalahan. Berdasarkan ketiga teknik tersebut diperoleh data tentang faktor kesulitan belajar matematika siswa MI Da'watul Falah Kecamatan Tegaldilmo Kabupaten Banyuwangi tahun pelajaran 2018/2019 sebagai berikut:

\section{Kesulitan Belajar Matematika Siswa MI Da'watul Falah Kecamatan Tegaldilmo Kabupaten Banyuwangi Tahun Pelajaran 2018/2019}

Kesulitan belajar matematika yang dialami siswa di MI Da'watul Falah Kecamatan Tegaldlimo Banyuwangi yaitu berasal dari persepsi awal siswa terhadap matematika yang kurang bagus, karena sebelum mereka belajar matematika mereka sudah menganggap bahwa matematika itu sulit.

\footnotetext{
${ }^{20}$ Matthew B. Miles, A. Michael Huberman, and Johnny Saldana, Qualitative Data Analysis: A Methods Sourcebook, Third Edit (United States of America: SAGE Publications, Inc, 2014).

${ }^{21}$ Sarah J Tracy, Qualitative Research Methods, First Edit (United Kingdom: WileyBlackwell, John Wiley \& Sons, Ltd., Publication, 2013).

${ }^{22}$ Creswell and Creswell, Research Design: Qualitative, Quantitative, and Mixed Methods Approaches.
} 
Jadi hal tersebut berpengaruh terhadap proses belajar siswa. Hal tersebut sesuai dengan teori yang dikemukakan oleh Abdurrahman sebelumnya bahwa kesulitan belajar dapat diklasifikasikan dalam dua kelompok yaitu yang pertama kesulitan belajar yang berhubungan dengan perkembangan. Kesulitan belajar yang berhubungan dengan perkembangan mencakup gangguan motorik dan persepsi, kesulitan belajar bahasa dan komunikasi, dan kesulitan belajar dalam penyesuaian perilaku sosial. ${ }^{23}$

Selanjutnya hal yang menyebabkan siswa kesulitan belajar yaitu mengenai materi. Banyak siswa yang mengeluhkan mengenai materi yang sudah mereka pelajari terutama materi tentang operasi hitung, seperti pembagian dan perkalian. Akan tetapi, ada beberapa siswa juga kesulitan dimateri selain operasi hitung, seperti materi mengenai rumus bangun ruang. Hal tersebut sesuai dengan teori yang dijelaskan oleh Daniel Franklin, sebelumnya bahwa kesulitan belajar adalah suatu kondisi yang menimbulkan hambatan dalam proses belajar seseorang. Hambatan tersebut menyebabkan orang tersebut mengalami kegagalan atau setidak-tidaknya kurang berhasil dalam mencapai tujuan belajar. ${ }^{24}$ Jadi dari hasil temuan penelitian di atas, dapat dikatakan bahwa terdapat kesesuaian antara teori dengan yang terjadi di lapangan tentang kesulitan belajar yang dialami oleh siswa MI Da’watul Falah Kecamatan Tegaldlimo Banyuwangi.

Faktor Internal Kesulitan Belajar Matematika Siswa MI Da'watul Falah Kecamatan Tegaldilmo Kabupaten Banyuwangi Tahun Pelajaran 2018/2019

Terdapat beberapa faktor internal yang menyebabkan siswa kesulitan dalam belajar matematika. Faktor-faktor tersebut diantaranya adalah sebagai berikut.

\footnotetext{
${ }^{23}$ Mulyono Abdurrahman, Anak Berkesulitan.

${ }^{24}$ Franklin, Helping Your Child with Language-Based Learning Disabilities: Strategies to Succeed in School \& Life with Dyslexia, Dysgraphia, Dyscalculia, ADHD \& Processing Disorders.
} 


\section{Minat}

Minat belajar matematika siswa di MI Da'watul Falah terdapat 2 macam yaitu ada yang minatnya tinggi ada juga yang minatnya rendah. Peneliti memperoleh siswa yang memiliki minat yang rendah lebih banyak yaitu sebanyak 54\% dari jumlah keseluruhan yang peneliti wawancarai. Siswa yang memiliki minat yang tinggi rata-rata ketika diminta mengerjakan tugas yang diberikan oleh guru mereka selalu mengerjakan tugas tersebut dengan tuntas dan semangat, akan tetapi siswa yang memiliki minat yang rendah dalam mata pelajaran matematika, ketika guru menjelaskan siswa tidak terlalu memperhatikan dan ketika diberi tugas mereka sebagian ada yang mengerjakan dengan bersama-sama atau melihat pekerjaan milik temannya dan juga ada yang tidak mengerjakan. Hal itu dikarenakanmereka malas untuk menyelesaikan tugas yang telah diberikan.

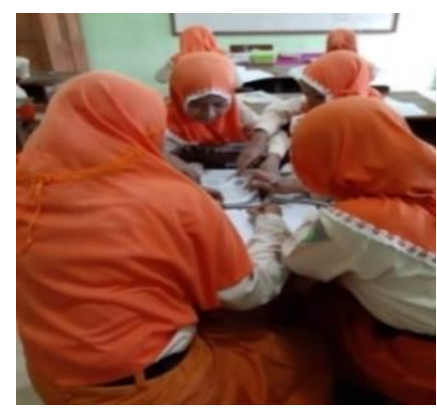

Gambar: Suasana Belajar Kelas 4

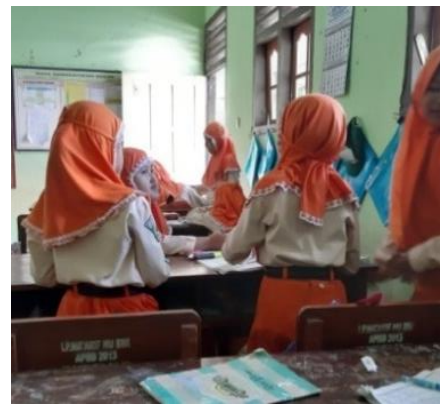

Gambar: Suasana Belajar Kelas 5

Hal tersebut sesuai dengan teori yang dikemukakan oleh Ahmadi dan Supriyono, bahwa salah satu faktor yang mempengaruhi kesulitan belajar siswa adalah minat, karena tidak adanya minat seseorang anak terdahap suatu pelajaran akan timbul kesulitan belajar. Belajar yang tidak ada minatnya mungkin tidak sesuai dengan bakatnya, tidak sesuai dengan kebutuhan, tidak sesuai dengan kecakapan, tidak sesuai dengan tipe-tipe khusus anak banyak menimbulkan problema pada dirinya. Karena itu pelajaranpun tidak pernah terjadi proses dalam otak, akibatnya timbul 
kesulitan belajar. ${ }^{25}$ Jadi dari hasil temuan diatas dapat ditarik kesimpulan bahwa tingginya persentase siswa yang tidak mempunyai minat terhadap mata pelajaran matematika di MI Da'watul Falah, dikarenakan tidak sesuainya bakat yang dimiliki oleh anak yang mengakibatkan terjadinya kesulitan belajar oleh siswa.

\section{Motivasi}

Motivasi siswa dalam belajar matematika tergolong rendah. Hal tersebut dapat dilihat dari siswa yang jarang belajar di rumah, meskipun ada PR dengan berbagai alasan misalnya karena malas, mengantuk, dan lain sebagainya. Meskipun ada PR mereka jarang mengerjakannya biasanya dikerjakan di tempat kursus atau dikerjakan bersama teman-temannya ketika di sekolah, tetapi ada juga sebagian siswa yang belajar meski tidak ada PR ataupun ulangan. Dan hanya sedikit siswa yang mengikuti kursus privat mata pelajaran matematika, rata-rata mereka mengikuti kursus yang mempelajari semua mata pelajaran. Dan dalam tempat kursus tersebut biasanya siswa tidak ada pelajaran baru, tetapi hanya mengerjakan tugas yang diberi oleh guru ketika disekolah. Hal tersebut sesuai dengan teori yang dikemukakan oleh Ahmadi dan Supriyono bahwa Motivasi dapat menentukan baik tidaknya dalam mencapai tujuan sehingga semakin besar motivasinya akan semakin besar kesuksesan belajarnya. Seorang yang besar motivasinya akan giat berusaha, tampak gigih tidak mau menyerah. Sebaliknya mereka yang motivasinya lemah, tampak acuh-tak acuh, mudah putus asa, perhatiannya tidak tertuju pada pelajaran, akibatnya banyak mengalami kesulitan belajar. ${ }^{26}$

Jadi dari hasil temuan diatas dapat ditarik kesimpulan bahwa motivasi siswa untuk belajar mata pelajaran matematika di MI Da'watul Falah tergolong rendah. Hal itu diakibatkan karena siswa kurang acuh dan mudah

\footnotetext{
${ }^{25}$ Ahmadi dan Supriyono, Psikologi Belajar.

${ }^{26}$ Ahmadi and Supriyono, Psikologi Belajar.
} 
putus asa dalam mempelajahi mata pelajaran matematika yang mengakibatkan siswa kesulitan dalam belajar matematika.

\section{Keadaan Fisik}

Keadaan fisik yang lemah yang dialami oleh siswa dapat mengganggu dalam proses belajarnya, misalnya siswa yang terlalu kelelahan, kemudian siswa yang mengalami gangguan pada indra penglihatannya. Gangguan yang dialaminya yaitu mata minus, hal tersebut mengakibatkan siswa menjadi sedikit kesulitan dalam melihat. Akan tetapi, tidak banyak siswa yang mengalami hal-hal tersebut di MI Da'watul Falah, hanya sebagian saja yang mengalami hal tersebut. Hal tersebut sesuai dengan teori yang dikemukakan oleh Ahmadi dan Supriyono sebelumnya, bahwa keadaan fisik yang kurang baik dapat menyebabkan penerimaan dan respons pelajaran berkurang, saraf otak tidak mampu bekerja secara optimal memproses, mengelola, menginterprestasi dan mengorganisasi bahan pelajaran melalui indra. $^{27}$

Jadi dari hasil temuan yang telah peneliti peroleh bahwa keadaan fisik yang lemah, yang terjadi pada siswa di MI Da'watul Falah mengakibatkan terjadinya gangguan terhadap kegiatan belajarnya, yang hal itu dapat mengakibatkan siswa mengalami kesulitan belajar. Berdasarkan hasil temuan diatas maka dapat ditarik kesimpulan bahwa faktor internal yang menyebabkan siswa kesulitan belajar yang dialami oleh siswa di MI Da'watul Falah sesuai dengan teori-teori yang dikemukakan oleh Ahmadi dan Supriyono.

Faktor Eksternal Kesulitan Belajar Matematika Siswa MI Da'watul Falah Kecamatan Tegaldilmo Kabupaten Banyuwangi Tahun Pelajaran 2018/2019

\section{Guru}

Guru mata pelajaran matematika di MI Da'watul Falah kurang melakukan variasi dalam kegiatan belajar, hal ini dapat dilihat dari cara guru

${ }^{27}$ Ibid, 89. 
ketika kegiatan belajar hanya menggunakan metode ceramah dan tanya jawab, selain itu guru juga jarang menggunakan media selain papan tulis dan buku mata pelajaran matematika. Akan tetapi, sesekali guru pernah melakukan sebuah usaha untuk meningkatkan ketertarikan siswa terhadap matematika, misalnya diajak membuat gambar bangun ruang, mengajak belajar di laboratorium, menggabungkan anak yang bisa untuk mengajari anak yang kurang bisa. Selain itu, sikap guru kepada siswa tergolong tegas dan fleksibel, akan tetapi dalam penanganan siswa yang nakal yang sudah tidak bisa diberi tau yaitu menggunakan sedikit cara kekerasan, dengan cara memukul dan melempar barang kecil kepada siswa.

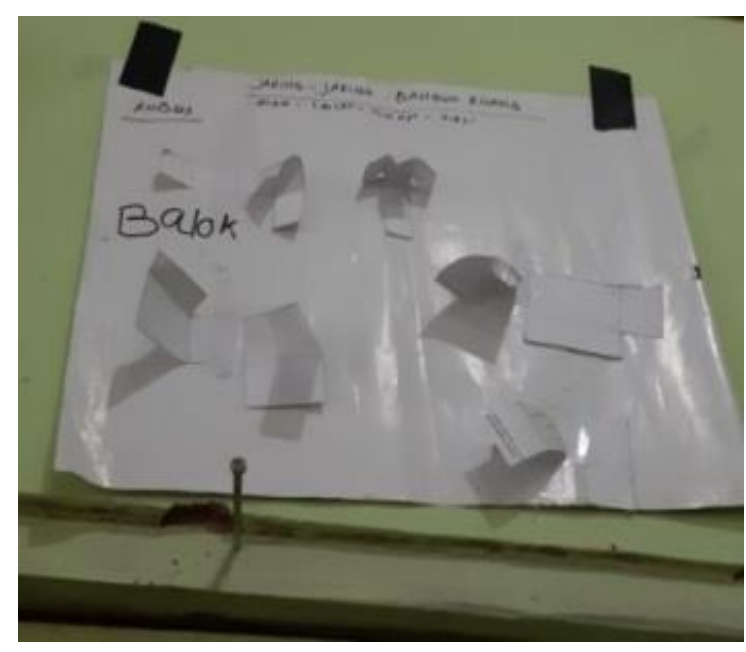

Gambar: Alat Peraga Bangun Ruang

Hal tersebut sesuai dengan teori yang dikemukakan oleh Ahmadi dan Supriono guru yang dalam kegiatan belajarnya memiliki hubungan yang kurang baik dengan murid serta tidak qualified dapat menjadi sebab siswa kesulitan belajar. Guru yang tidak qualified, baik dalam pengambilan metode yang digunakan atau dalam mata pelajaran yang dipegangnya. Hal tersebut bisa terjadi, karena hak yang dipegangnya kurang sesuai, hingga kurang menguasai, lebih-lebih kalau kurang persiapan, sehingga cara menerangkan kurang jelas, sukar dimengerti oleh murid-muridnya. Selain itu, hubungan guru dengan murid yang kurang baik, seperti kasar, suka 
marah, tak pandai menerangkan, tak adil, dan lain-lain. Sikap-sikap guru seperti itu tidak disenangi oleh murid, hingga menghambat perkembangan anak dan mengakibatkan hubungan guru dengan murid tidak baik. ${ }^{28}$

Jadi dari hasil temuan yang peneliti peroleh bahwa guru mata pelajaran matematika yang ada di MI Da'watul Falah kurang melakukan pengembangan strategi pembelajaran yang menjadikan kegiatan belajar yang terjadi terkesan monoton dan siswa menjadi kurang semangat ketika kegiatan belajar berlangsung.

\section{Keluarga}

Siswa ketika belajar ditemani oleh orang tua mereka, ada juga yang ditemani oleh saudaranya seperti kakaknya. Akan tetapi dalam pendampingan orang tuanya berbeda-beda ada yang mengajari anaknya, ada yang hanya menemani, dan ada juga yang hanya menemani ketika anak tersebut mengalami kesulitan. Hal tersebut sesuai dengan teori yang dikemukakan oleh Ahmadi dan Supriyono, bahwa keluarga dapat juga menjadi faktor penyebab kesulitan belajar. Sifat kasih sayang penuh pengertian, atau kebencian, sikap keras, acuh tak acuh, memanjakan dan lain-lain. Kasih sayang dari orangtua, perhatian atau penghargaan kepada anak-anak menimbulkan mental yang sehat bagi anak, akan tetapi kurangnya kasih sayang akan menimbulkan emosional insencurity. Demikian juga sikap keras, kejam, acuh tak acuh akan menyebabkan seorang anak kesulitan/kesukaran belajar. ${ }^{29}$

Jadi dari hasil temuan yang peneliti peroleh bahwa orangtua dari siswa di MI Da'watul Falah kurang terlalu memperhatikan proses kegiatan belajar yang dilakukan oleh anak, yang mana seharusnya orangtua harus mendampingi anaknya untuk bisa mencapai tujuan belajarnya.

\footnotetext{
${ }^{28}$ Ahmadi dan Supriyono, Psikologi Belajar, 89.

${ }^{29}$ Ahmadi dan Supriyono, Psikologi Belajar, 86-87.
} 


\section{Sarana dan Prasarana}

Sarana dan prasana yang ada di MI Da'watul Falah ini memenuhi kurang lebih sekitar 60-75\%. Kendalanya ada pada kekurangan media belajar seperti buku dan alat peraga. Untuk kendala buku, MI Da'watul Falah kekurangan dalam buku mata pelajaran dan mengakibatkan minimnya buku yang bisa dipakai oleh siswa, serta karena pergantian kurikulum dan otomatis harus ada buku baru, akan tetapi buku untuk kurikulum terbaru juga belum rilis dan hal itu menjadikan hambatan untuk guru dalam proses kegiatan belajar. Selain itu kendala untuk alat peraga, dikarenakan tidak dirawat dengan baik sehingga mengakibatkan alat peraga tersebut tidak terurus dan menjadi rusak. Akan tetapi sekolah dapat mensiasati kendalakendala tersebut dengan apa yang ada, misalnya dengan memfotocopy buku yang sudah ada, membenahi alat peraga yang masih bisa dibenahi, memanfaatkan apa yang ada disekitarnya.
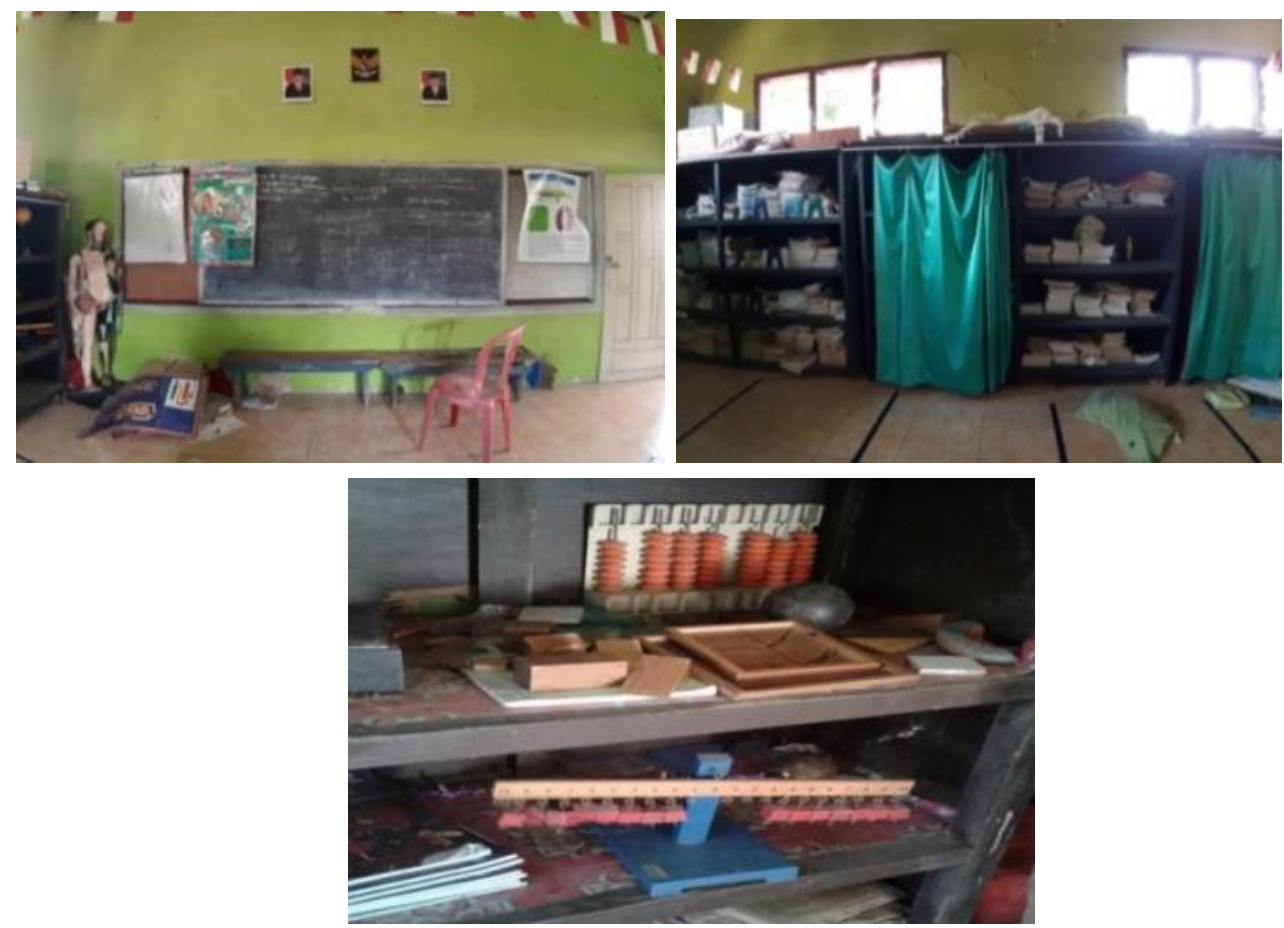

Gambar: Alat Pelajaran dan Buku di MI Da’watul Falah 
Hal tersebut sudah sesuai dengan teori yang dikemukakan oleh Maryani, dkk. sebelumnya bahwa Sarana dan prasarana pembelajaran merupakan faktor yang turut memberikan pengaruh terhadap hasil belajar siswa. Dari dimensi guru ketersediaan sarana dan prasarana akan memberikan kemudahan dalam kegiatan pembelajaran dan mendorong terwujudnya pembelajaran yang efektif. Sedangkan dari dimensi siswa ketersediaan sarana dan prasarana memberikan dampak terciptanya iklim pembelajaran yang lebih kondusif, memberikan kemudahan kepada siswa untuk mendapatkan informasi serta mendorong tumbuh dan berkembangnya motivasi belajar siswa untuk mencapai hasil belajar yang lebih baik. ${ }^{30}$

Jadi dari hasil temuan yang peneliti peroleh bahwa di MI Da'watul Falah sudah cukup menunjang untuk kegiatan belajar matematika. Akan tetapi ada sarana dan prasarana yang perlu diperbarui seperti buku siswa, buku bacaan, serta alat peraga, karena buku yang dipakai masih menggunakan buku yang edisi lama.

\section{Lingkungan Sosial}

Siswa di MI Da'watul Falah ini dalam berteman ada yang pilih-pilih ada juga yang berteman dengan semua. Alasan sebagian siswa pilih-pilih dalam berteman karena mereka kurang merasa nyaman dengan teman yang lain, serta ada yang berpikir bahwa temannya yang lain hanya mau berteman dengan yang pintar saja. Hal tersebut sesuai dengan teori yang dikemukakan oleh Maryani, dkk. bahwa lingkungan sosial yang ada dapat memberikan pengaruh yang positif dan pengaruh negatif. Lingkungan sosial yang terpengaruh pengaruh negatif tidak akan menguntungkan untuk siswa, karena itu akan berdampak terhadap berubahan tingkah laku siswa. ${ }^{31}$

Jadi dari temuan diatas peneliti menemukan bahwa teman sebaya sangat berpengaruh terhadap kegiatan belajar siswa, karena siswa yang

\footnotetext{
${ }^{30}$ Maryani et al., Model Intervensi: Gangguan Kesulitan Belajar.

${ }^{31}$ Ibid, 18.
} 
awalnya bisa fokus dalam belajar kemudian ketika ada siswa yang mengajak bermain hal itu bisa membuat fokus belajar siswa jadi pudar, selain itu teman yang baik juga berpengaruh terhadap semangat belajar siswa.

\section{SIMPULAN}

Berdasarkan hasil dan pembahasan di atas, dapat disimpulkan bahwa kesulitan belajar matematika yang dialami oleh siswa di MI Da'watul Falah disebabkan karena salahnya mindset yang dibangun dari awal oleh siswa yang menganggap bahwa matematika itu mata pelajaran sulit, selain itu kesulitan yang dialami juga berasal dari materi. Faktor-faktor internal yang mempengaruhi kesulitan belajar siswa terhadap matematika adalah minat, motivasi dan kondisi fisik. Sedangkan faktor-faktor eksternal yang mempengaruhi kesulitan belajar siswa terhadap matematika berasal dari guru. Selain itu, hubungan dalam keluarga siswa, sarana dan prasana belajar yang disediakan sekolah serta lingkungan sosial siswa sangat berpengaruh terhadap kesulitan belajar matematika siswa.

Diharapkan untuk peneliti selanjutnya yang ingin meneliti tentang faktor kesulitan belajar matematika siswa, lebih mendalami atau memfokuskan pada salah satu faktor yang menjadi tolak ukur pertama penyebab siswa kesulitan belajar matematika, sehingga bisa diketahui faktor terbesar penyebab siswa mengalami kesulitan belajar matematika.

\section{DAFTAR PUSTAKA}

Abdurrahman, Mulyono. Anak Berkesulitan Belajar (Teori, Diagnosis, Dan Remediasinya). Jakarta: Rineka Cipta, 2012.

Abdurrahman, Mulyono. Pendidikan Bagi Anak Berkesulitan Belajar. Jakarta: Rineka Cipta, 2010. 
Ahmadi, Abu, and Widodo Supriyono. Psikologi Belajar. Jakarta: Rineka Cipta, 2013.

Creswell, John W., and J. David Creswell. Research Design: Qualitative, Quantitative, and Mixed Methods Approaches. Fitth Edit. United States of America: SAGE Publications, Inc, 2018.

Emzir. Metodologi Penelitian Kualitatif Analisis Data. Jakarta: Rajawali Pers, 2016.

Fokusmedia, Tim. Undang-Undang SISDIKNAS Sistem Pendidikan Nasional. Bandung: Fokus Media, 2015.

Franklin, Daniel. Helping Your Child with Language-Based Learning Disabilities: Strategies to Succeed in School \& Life with Dyslexia, Dysgraphia, Dyscalculia, ADHD \& Processing Disorders. Canada: New Harbinger Publications, 2018.

Jamaris, Martini. Kesulitan Belajar: Perspektif, Asesmen, Dan Penanggulangannya. Bogor: Ghalia Indonesia, 2015.

Kholil, Mohammad. "Implementasi Pembelajaran Inquiry Untuk Meningkatkan Kemampuan Berpikir Logis Pada Pokok Bahasan Logika Matematika." LAPLACE: Jurnal Pendidikan Matematika 1, no. 1, 2018.

Kholil, Mohammad. "Membangun Kemampuan Koneksi Matematika Melalui Strategi Interaksi Peserta Didik Program Studi Pendidikan Guru Madrasah Ibtidaiyah (PGMI) Institut Agama Islam Negeri (IAIN) Jember.” FENOMENA 15, No. 2 December 29, 2016.

Kholil, Mohammad, and Olvi Safianti. "Efektivitas Pembelajaran Penemuan Terbimbing Terhadap Hasil Belajar Matematika Siswa Materi Barisan Dan Deret." Laplace: Jurnal Pendidikan Matematika 2, No. 2 November 25, 2019.

Maryani, Ika, Laila Fatmawati, Vera Yuli Erviana, M. Nur Wangid, and Ali Mustadi. Model Intervensi: Gangguan Kesulitan Belajar. Jogjakarta: K-Media, 2018.

MENDIKBUD. Peraturan Menteri Pendidikan Dan Kebudayaan Republik Indonesia Nomor 21 Tahun 2016 Tentang Standar Isi Pendidikan Dasar Dan Menengah. Jakarta: Menteri Pendidikan dan Kebudayaan, 2016.

Miles, Matthew B., A. Michael Huberman, and Johnny Saldana. Qualitative Data Analysis: A Methods Sourcebook. Third Edit. United States of America: SAGE Publications, Inc, 2014.

Schiff, Rachel., and R. Malatesha. Joshi. Interventions in Learning Disabilities: A Handbook on Systematic Training Programs for 
Individuals with Learning Disabilities. Switzerland: Springer International Publishing, 2016.

Sugiyono. Metode Penelitian Pendidikan (Pendekatan Kuantitatif, Kualitatif Dan R\&D). Bandung: Penerbit CV. Alfabeta, 2017.

Tracy, Sarah J. Qualitative Research Methods. First Edit. United Kingdom: Wiley-Blackwell, John Wiley \& Sons, Ltd., Publication, 2013.

Waskitoningtyas, Rahayu Sri. "Analisi Kesulitan Belajar Matematika Siswa Kelas V Sekolah Dasar Kota Balikpapan Pada Materi Satuan Waktu.” Jurnal Ilmiah Pendidikan Matematika 5, No. 1, 2016. 